\title{
Quality Evaluation of Extrudates from Defatted Cashew Nut Flour and Whole Oat Flour
}

\author{
H.T. Olaleye, T.O. Oresanya, Z.O.Abdullahi, and E.I. Anderson
}

\begin{abstract}
Access to affordable nutritious foods and development of new food product with an intention to bridge a gap are some of the ways food security can be achieved. This study was conducted to produce extrudates from defatted cashew nut- whole oats flour and to determine the effects of ingredients combination on the nutritional quality of the extrudates. Cashew nut and Oats were processed into flours with pre-calculated amount of carboxyl-methyl cellulose to attain good textural properties. Extrusion was performed at predetermined feed moisture (11\%), screw speed of (110rpm) and barrel temperature $\left(90^{\circ} \mathrm{C}\right)$. Proximate and functional properties of blend ratios as well as proximate, functional, textural and sensory evaluation of the extrudates were determined. Extrusion cooking reduced the moisture content but increased the protein and crude fibre of the extrudates. Texture profile analysis showed that as oats flour increased the hardness and chewiness also increased. Sample $\mathrm{O}_{75} \mathrm{C}_{25}$ was rated most acceptable with regards to the overall acceptability. The best extrudates with high protein-crude fibre and chewiness was made from $75 \%$ whole oat flour to $25 \%$ defatted cashew nut flour. Functional extrudates can be made from defatted cashew nut and oat flour which can serve as a functional food.
\end{abstract}

Key words-Cashew nut flour, Defatted, Extrudates, Functional Foods, Whole Oat flour.

\section{INTRODUCTION}

Eating consciously is important due to increasing health issues and conditions as a result of malnutrition, lack of knowledge about food composition and 'filling up space syndrome'. When food is consumed with health intent then a lot of health issues arising from not eating right would have been avoided. Functional foods are nutritious natural or processed foods with active ingredient that aids specific bodily functions.

Functional foods are usually deliberately added to food for a beneficial purpose that goes beyond what are known as traditional nutritional effects. They can be obtained from plant sources such as oats, soya bean, flax seed, tomatoes and animal sources such as fish, diary product and beef. Oats and cashew nuts fits perfectly into examples of functional foods because of their associated compounds which aid in digestion of foods and lowering of cholesterol etc. [1].

Oat (Avena sativa), is a cereal grown for its seed with minimal food uses despite is nutritional advantages. Its

Published on June 14, 2020.

H. T. Olaleye, Yaba College of Technology, Lagos, Nigeria. (email: hannah.olaleye@yabatech.edu.ng)

T. O. Oresanya, Yaba College of Technology, Lagos, Nigeria.

(email: tolulope.oresanya@yabatech.edu.ng) protein is considered to be more nutritious than most cereals consumed today. Oats utilization is mostly limited to breakfast oatmeal, rolled oats, and livestock feed while some people eats oats as it is perceived to have cholesterol lowering properties due to high $\beta$ glucan content. The protein ranges between $15 \%$ and $20 \%$ with perfect essential amino acids having little or no anti-nutritional factors that could hinder the bio-availability of the proteins [2].

Cashew (Anacardium occidentale) is a kidney or heart shaped achene which is made up of apple that has its fruit embedded in it. It is considered to have one economic importance or the other, because its component has different economic values. Economically, Nigeria has become a market for cashew export as it is one of the cash crops that generates appreciable amount of foreign exchange to the country. Nutritionally, cashew is a nutrient dense crop with appreciable amount of essential amino acid, carbohydrate, essential fatty acid, macro nutrients and phytochemicals [3].

Extrusion of food involves the use of heat (hot or cold), high pressure and shear forces to a food material [4]. It is a continuous process that is easy to prepare different types of cheap food products in various shapes and textures. The use of oats- defatted cashew nuts composite flour in the preparation of extrudates can be used as a tool against the challenges of protein, vitamin and phytochemical deficiencies which are underlying causes for proper growth and development of growing children and adults in Nigeria. The focus of the study was to produce extrudates from two nutrient dense ingredients; cashew nut, a low fibre nut packed with vitamins, minerals and anti-oxidants and oats, considered to be a healthy food due to its rich content such as different essential nutrients and cholesterol lowering properties and thus investigate the combination of these flours on the nutritional quality of the extrudates.

\section{MATERIALS AND METHODS \\ A. Raw Material}

Cashew nuts were supplied by Olam Nigeria Limited, Kwara state, Nigeria, while the Oat was obtained from Bulk-Barn, Weston Road Toronto, Ontario, Canada. Corn Starch and granulated sugar were bought at a local store in Lagos, Nigeria.

Z. O. Abdullahi, Yaba College of Technology, Lagos, Nigeria (email: omoze.abdullahi@yahoo.com)

E. M. Anderson, Yaba College of Technology, Lagos, Nigeria. (email: dupe.andy95@yahoo.com) 


\section{B. Preparation of sample}

\section{Defatted Cashew Nut Flour (DCNF)}

The defatted cashew nuts flour was made, following the modified method described by [5]. Five kilograms of processed cashew nuts was milled using an attrition mill (k131, Nigeria) and defatted using N-Hexane (1:5, w/v, cashew meal to N-hexane) with continuous stirring for $3 \mathrm{~h}$ at room temperature (RT) and filtered with a muslin cloth. The slurry was defatted until $10 \%$ fat content was achieved and this was ascertained using soxhlet extraction method of lipid analysis to ascertain the final fat content. The residual Nhexane was evaporated by drying in a cabinet drier (D28, Nigeria) at $50^{\circ} \mathrm{C}$. Resultant cake was milled and packaged until further analysis as seen in Figure 1.

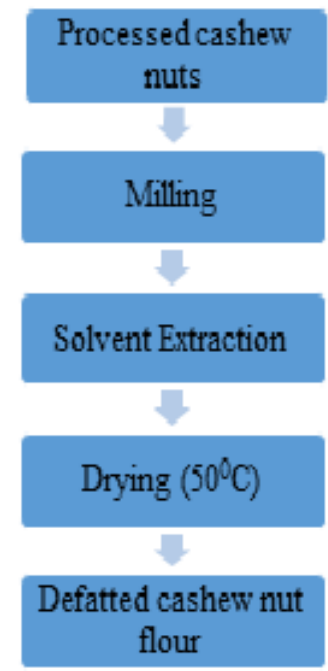

Figure 1: Flow Chart of Defatted Cashew Nut Flour Source: (Ogunwolu and Ogunjobi, 2010)

\section{Oat Flour}

Oat was washed with clean water to remove contaminants, dried at $50^{\circ} \mathrm{C}$ for $2 \mathrm{hrs}$, and milled into flour as seen in Figure 2.

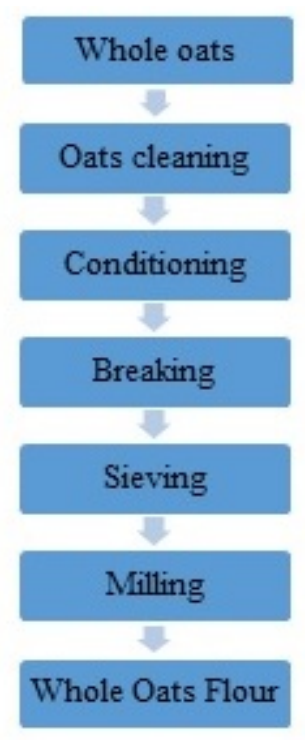

Figure 2: Flowchart for the processing of Oat Flour

\section{FORMULATION OF FLOUR BLENDS}

Simplex lattice mixture design was used to obtain different percentages for Defatted cashew nut flour (DCNF) and Whole Oats (OF) at percentage presented in Table 1 after a preliminary trial.

TABLE I: BLENDS OF DEFATTED CASHEW NUT AND OATS FLOUR BASED SIMPLEX LATTICE DESIGN

\begin{tabular}{lll}
\hline Samples & Oats (g) & Cashew (g) \\
\hline $\mathbf{O}_{65} \mathbf{C}_{35}$ & 65 & 35 \\
$\mathbf{O}_{70} \mathbf{C}_{30}$ & 70 & 30 \\
$\mathbf{O}_{60} \mathbf{C}_{40}$ & 60 & 40 \\
$\mathbf{O}_{75} \mathbf{C}_{25}$ & 75 & 25 \\
$\mathbf{O}_{60} \mathbf{C}_{40}$ & 60 & 40 \\
$\mathbf{O}_{80} \mathbf{C 2 0}_{20}$ & 80 & 20 \\
$\mathbf{O}_{80} \mathbf{C}_{20}$ & 80 & 20 \\
$\mathbf{O}_{70} \mathbf{C}_{30}$ & 70 & 30 \\
\hline
\end{tabular}

Where $\mathrm{X}_{1}+\mathrm{X}_{2}=1$ or $100 \%$ with 3 Center points.

\section{Extrusion processing}

Extrusion cooking was done using with a locally fabricated single screw extruder with L/D ratio of 304:18.5 and diameter screw of $18 \mathrm{~mm}$. Also, the extruder operated with $2 \mathrm{hp}$ and barrel length of $304 \mathrm{~mm}$ respectively. The extruder was operated at screw speed (110rpm) and barrel temperature $\left(90^{\circ} \mathrm{C}\right)$ for all the runs. Defatted cashew nut, oat flours and carboxyl-methylcellulose (CMC) were thoroughly mixed in a blender at predetermined feed moisture (10-15\%) and kept in cold storage for $8 \mathrm{~h}$. The dough was brought out and allowed to rest for an hour for equilibrium at room temperature before extrusion cooking to ensure uniformity of mixture and hydration of the paste.
It was fed into the extruder according to the blend ratios in Table I. The Oat flour and defatted cashew nut flour percentage was varied according to the blend ratios while other ingredients such as carboxyl-methylcellulose (CMC) $(25 \mathrm{~g} / \mathrm{kg})$ and sugar $(3 \mathrm{~g})$ were kept constant across the mixture [6].

\section{Proximate analysis of the flour blends and extrudates}

Proximate composition (Moisture, crude protein, crude fat, crude fibre and total ash and carbohydrate by difference) of the flour and extrudates was determined according to AOAC [7]. 


\section{Functional analysis of the Flour Blends}

Swelling power and solubility index

The swelling power and solubility index were carried out by the method of Robertson et al. [8]

$$
\begin{aligned}
& \text { Solubilityindex }(\%) \\
& =\frac{\text { Weightofdrysolidsafter drying }}{\text { Weight of sample }} \times 100 \\
& \text { Swellingpower } \\
& =\frac{\text { Weightofthewetmassof sediment }}{\text { Weightofdrymatterinthegel }} \times 100
\end{aligned}
$$

Oil and Water absorption capacity

Oil and water absorption capacity was determined using the method described by Ade-Omowaye et al. [9]. WAC was calculated using:

$$
\begin{aligned}
& \text { Waterabsorptioncapacity } \\
& =\frac{\text { Weight oftube }+ \text { Sediment }- \text { Weightofemptytube }}{\text { Weightof sample }}
\end{aligned}
$$

\section{Bulk Density}

Bulk density was determined using the method described by [10] and it was calculated as stated below:

$$
\text { Bulkdensity } \frac{\mathrm{g}}{\mathrm{ml}}=\frac{\text { weight of sample }}{\text { volume of sample after tapping }}
$$

\section{Pasting characteristics of the flour}

The pasting characteristics of the flour samples Pasting analysis of the formulations was analyzed with Rapid Viscosity Analyzer (RVA), (model DA, 6200 $\left.{ }^{\mathrm{TM}} \mathrm{NIR}, \mathrm{UK}\right)$ [11].

\section{E. Functional properties of extrudates}

\section{Expansion Ratio}

The diameter ratio of the extrudates and the die diameter were used to calculate the expansion ratio of the extrudates [12]. The diameter of the extrudates were randomly measured using a Vernier caliper and calculated as:

$$
\text { ExpansionRatio }=\frac{\text { Diameter of extrudate } / \mathrm{mm}}{\text { Diameter of the die } / \mathrm{mm}}
$$

\section{F. Textural properties of the extrudates}

The hardness and fracturability of the samples was determined by the procedure of[13] using a texture analyzer (model TA.HDi Texture Technologies Corp. Scarsdale, NY/Stable micro System, Godalming, Surrey, UK)

\section{G. Consumer Acceptance test}

The acceptance of the extrudates were examined by 30 panelists familiar with extruded products [14]. The parameters measured were texture, taste, colour, aroma, texture and overall acceptability using a9-point structured hedonic scale (1-dislike extremely and 9-like extremely).

\section{H. Statistical Analysis}

Data generated were statically analyzed using ANOVA of the Statistical Package for Social Science (SPSS), version 18.0. Means of the values were separated using Duncan multiple range test at $5 \%$ level of significance $(p<0.05)$.

\section{RESULTS AND DISCUSSION}

\section{A. Proximate Analysis of the Flour and Extrudates}

The results for proximate analysis of the flour samples is presented in Table II. Significant differences were observed or exist in the mean scores of proximate composition of defatted cashew nut and oat flour blends Protein, moisture, crude fat, ash, fibre, and carbohydrates content ranged from 7.41 to $19.65 \%, 5.87$ to $6.68 \%, 6.86$ to $11.62 \%, 1.47$ to $2.04 \%, 0.50$ and $1.35 \%$, and 59.79 to $73.81 \%$ respectively. Oat flour substituted with defatted cashew nut flour at $40 \%$ had the least value and sample O80C20 the highest value. The moisture content decreased as defatted cashew nut flour increased. Moisture content is an index of storability and shelf stability. Increased moisture content can cause a rapid growth of microbes which could lead to food quality deterioration [15]. The moisture content was lower than the (12-14\%) moisture content suggested for shelf-stability for flours or powdered food [16]. Therefore, the low values obtained in this study will reduced the possibility of microbial attack and would thus increase its shelf life.

The protein content increased as defatted cashew nut flour substitution increased. Sample $\mathrm{O}_{80} \mathrm{C}_{20}$ had the least and $\mathrm{O}_{60} \mathrm{C}_{40}$ had the highest protein content. [17] reported that the observed gradual increase can be associated to the protein content of the defatted cashew nut flour as Oat has been reported to be low in protein [18]. Thus the addition of defatted cashew nut flour improved the overall quantity of protein of the flour blends as the addition increased.

The crude fat values are significantly different from each other. Sample $\mathrm{O}_{75} \mathrm{C}_{25}$ had the least value while $\mathrm{O}_{60} \mathrm{C}_{40}$ had the highest crude fat content. The crude fat increased as cashew nut flour increased. [19] reported that oat has about 4-9\% of lipids, while cashew nut is classified as an oily seed. Fat is important in food processing because it helps to impart unique flavour to food and aids the digestion and absorption of fat soluble vitamins [19]. However, increase in the fat content could lead to rancidity and reduce the affect the shelf stability of the flour blends.

Sample $\mathrm{O}_{70} \mathrm{C}_{30}$ and $\mathrm{O}_{60} \mathrm{C}_{40}$ had the least and highest crude fibre content in the flour blends respectively. Significant difference $(p<0.05)$ was observe across the blends in the crude fibre content.[21] reported that high fibre content in oat, (such as bran) can increase the water holding capacity of the flour which is one of the important parameter for reconstitution 
extruded products.

Ash content of the samples had a different trend as the samples with defatted cashew nut flour inclusion level of 35 and $40 \%$ were totally different from other blends. Sample $\mathrm{O}_{75} \mathrm{C}_{25}$ had least ash content and samples $\mathrm{O}_{70} \mathrm{C}_{30}$ the highest. Ash content, is used to measure the amount of mineral element in food after complete combustion of the organic materials in food, it increased as the cashew nut flour increased. [22] reported (4.4\%) for cashew content of cashew nut that could account for increase in ash content as substitution of defatted cashew nut increased.

Carbohydrates content of the flour blends increased as defatted cashew nut flour inclusion decreased. The oat flour is reported to be a good source of starch. [23], reported that inclusion of oat flour generally increased the starch content of composite flour. Sample $\mathrm{O}_{65} \mathrm{C}_{35}$ and $\mathrm{O}_{80} \mathrm{C}_{20}$ had the least and highest carbohydrate content respectively.

The results for the proximate analysis of the extruded products are presented in Table III. There were significant $(\mathrm{p} \leq 0.05)$ differences across the sample values and across the proximate parameters. The moisture, protein, crude fat, fibre, ash and carbohydrates had values ranged from 5.84 to $7.24,10.85$ to $15.72,8.01$ to $11.13,0.46$ to $0.98,1.44$ to 2.48 and 63.58 to $772.26 \%$ respectively.

The moisture content of the extrudates determined varied between 5.65 and $7.24 \%$. Low moisture content values obtained in this study implies that the possibility of microbial growth is low and would thus increase the shelf-stability of the extrudates. Literature has demonstrated that differences in the moisture content of extrudates is a function of the percentage feed moisture and the temperature at which extrusion was done [24].

The protein content increased with increase in defatted cashew nut flour. Sample $\mathrm{O}_{60} \mathrm{C}_{40}$ had least protein and sample $\mathrm{O}_{65} \mathrm{C}_{35}$ the highest value for protein content. Proteins values shows that substitution of defatted cashew nut flour to the blends increased the protein content of all the extrudates. The increase in protein may be attributed to increased protein upon defatting of cashew nut which made all the protein matrix attached to the starch to become loose hence a higher percentage of protein in the defatted cashew nut flour and invariably the extrudates. Similar results were obtained by [25] who reported the same pattern of increase for corn and rice based extrudates.

Crude fibre content also increased as the defatted cashew nut flour inclusion increased. Sample $\mathrm{O}_{70} \mathrm{C}_{30}$ had the least crude fibre and sample $\mathrm{O}_{60} \mathrm{C}_{40}$ the highest. It is reported that food material that are naturally high in fibre like oats may contribute to higher water absorption capacity and invariably the final moisture of the extrudates. High fibre content can also exhibit a positive influence on the expansion of extruded snack while the ash content did not follow a particular trend, sample $\mathrm{O}_{75} \mathrm{C}_{25}$ had the least total ash and sample $\mathrm{O}_{70} \mathrm{C}_{30}$ the highest. The carbohydrate content of the extrudates increased as the defatted cashew nut inclusion reduced. Sample $\mathrm{O}_{65} \mathrm{C}_{35}$ had least carbohydrate content and sample $\mathrm{O}_{80} \mathrm{C}_{20}$ had the highest. Oat is a rich source of starch. [26], stated that the inclusion of oat flour generally increase the starch component of the composite flour.

TABLE II. PROXIMATE COMPOSITION OF OAT AND DEFATTED CASHEW NUT FLOUR BLENDS

\begin{tabular}{|c|c|c|c|c|c|c|}
\hline Ratios & $\begin{array}{l}\text { Moisture } \\
\text { Content } \\
(\%) \\
\end{array}$ & $\begin{array}{l}\text { Crude Protein } \\
(\%)\end{array}$ & $\begin{array}{l}\text { Crude fat } \\
\text { (\%) }\end{array}$ & $\begin{array}{l}\text { Crude Fibre } \\
\text { (\%) }\end{array}$ & $\begin{array}{l}\text { Total Ash } \\
\text { (\%) }\end{array}$ & $\begin{array}{l}\text { Carbohydrate } \\
(\%)\end{array}$ \\
\hline O65C35 & $6.13^{b} \pm 0.39$ & $7.41^{\mathrm{a}} \pm 0.04$ & $9.68^{c} \pm 0.15$ & $0.94^{\mathrm{b}} \pm 0.06$ & $2.04^{\mathrm{c}} \pm 0.04$ & $73.81^{\mathrm{d}} \pm 0.01$ \\
\hline O70C30 & $5.87^{\mathrm{a}} \pm 0.18$ & $11.44^{\mathrm{c}} \pm 0.08$ & $9.90^{c} \pm 0.09$ & $1.00^{\mathrm{b}} \pm 0.01$ & $1.47^{\mathrm{a}} \pm 0.08$ & $70.33^{b} \pm 0.30$ \\
\hline $\mathrm{O} 60 \mathrm{C} 40$ & $5.83^{\mathrm{a}} \pm 0.55$ & $19.65^{\mathrm{d}} \pm 0.71$ & $11.62^{\mathrm{d}} \pm 0.01$ & $1.21^{\mathrm{c}} \pm 0.01$ & $1.91^{\mathrm{b}} \pm 0.13$ & $59.79^{\mathrm{a}} \pm 0.05$ \\
\hline $\mathrm{O} 75 \mathrm{C} 25$ & $6.11^{\mathrm{b}} \pm 0.37$ & $11.78^{\mathrm{c}} \pm 0.04$ & $6.86^{\mathrm{a}} \pm 0.23$ & $1.35^{\mathrm{d}} \pm 0.01$ & $1.50^{\mathrm{a}} \pm 0.02$ & $72.39^{c} \pm 0.63$ \\
\hline $\mathrm{O} 60 \mathrm{C} 40$ & $5.83^{\mathrm{a}} \pm 0.55$ & $19.65^{\mathrm{d}} \pm 0.71$ & $11.62^{\mathrm{d}} \pm 0.01$ & $1.21^{\mathrm{c}} \pm 0.01$ & $1.91^{\mathrm{b}} \pm 0.13$ & $59.79^{\mathrm{a}} \pm 0.05$ \\
\hline $\mathrm{O} 80 \mathrm{C} 20$ & $6.68^{\mathrm{c}} \pm 0.41$ & $9.63^{b} \pm 0.09$ & $9.22^{\mathrm{b}} \pm 0.08$ & $0.50^{\mathrm{a}} \pm 0.01$ & $1.47^{\mathrm{a}} \pm 0.18$ & $72.50^{c} \pm 0.22$ \\
\hline $\mathrm{O} 80 \mathrm{C} 20$ & $6.68^{\mathrm{c}} \pm 0.41$ & $9.63^{b} \pm 0.09$ & $9.22^{\mathrm{b}} \pm 0.08$ & $0.50^{\mathrm{a}} \pm 0.01$ & $1.47^{\mathrm{a}} \pm 0.18$ & $72.50^{c} \pm 0.22$ \\
\hline O70C30 & $5.87^{a} \pm 0.18$ & $11.44^{\mathrm{c}} \pm 0.08$ & $9.90^{c} \pm 0.09$ & $1.00^{\mathrm{b}} \pm 0.01$ & $1.47^{\mathrm{a}} \pm 0.08$ & $70.33^{\mathrm{b}} \pm 0.30$ \\
\hline
\end{tabular}

Values are means duplicates \pm standard deviation. Different alphabets within a column are significantly different from each other ( $\mathrm{p} \leq 0.05$ ). $\mathrm{O}=$ oat flour, $\mathrm{C}=$ Defatted cashew nut flour

TABLE III. PROXIMATE ANALYSIS OF OAT AND CASHEW NUT FLOUR EXTRUDATES

\begin{tabular}{|c|c|c|c|c|c|c|}
\hline Ratios & $\begin{array}{c}\text { Moisture } \\
(\%)\end{array}$ & $\begin{array}{c}\text { Protein } \\
(\%)\end{array}$ & $\begin{array}{c}\text { Crude Fat } \\
(\%)\end{array}$ & $\begin{array}{l}\text { Crude Fibre } \\
(\%)\end{array}$ & $\begin{array}{l}\text { Total Ash } \\
(\%)\end{array}$ & $\begin{array}{l}\text { Carbohydrates } \\
(\%)\end{array}$ \\
\hline O65C35 & $7.24^{\mathrm{c}} \pm 0.14$ & $15.72^{\mathrm{e}} \pm 0.04$ & $11.13^{\mathrm{d}} \pm 0.14$ & $0.50^{\mathrm{b}} \pm 0.03$ & $1.85^{\mathrm{ab}} \pm 0.28$ & $63.58^{\mathrm{a}} \pm 0.36$ \\
\hline O70C30 & $7.07^{\mathrm{b}} \pm 0.15$ & $14.54^{\mathrm{d}} \pm 0.22$ & $7.82^{\mathrm{b}} \pm 0.09$ & $0.48^{\mathrm{a}} \pm 0.00$ & $2.48^{\mathrm{b}} \pm 0.22$ & $67.63^{\mathrm{b}} \pm 0.07$ \\
\hline O60C40 & $5.65^{\mathrm{a}} \pm 0.24$ & $10.85^{\mathrm{a}} \pm 0.05$ & $9.29^{c} \pm 0.21$ & $0.98^{\mathrm{c}} \pm 0.02$ & $1.66^{\mathrm{a}} \pm 0.03$ & $71.57^{\mathrm{c}} \pm 0.52$ \\
\hline $\mathrm{O} 75 \mathrm{C} 25$ & $6.95^{\mathrm{b}} \pm 0.01$ & $11.56^{\mathrm{b}} \pm 0.00$ & $8.01^{\mathrm{b}} \pm 0.04$ & $0.47^{\mathrm{a}} \pm 0.02$ & $1.44^{\mathrm{a}} \pm 0.41$ & $71.56^{\mathrm{c}} \pm 0.44$ \\
\hline O60C40 & $5.65^{\mathrm{a}} \pm 0.24$ & $10.85^{\mathrm{a}} \pm 0.05$ & $9.29^{c} \pm 0.21$ & $0.98^{\mathrm{c}} \pm 0.02$ & $1.66^{\mathrm{a}} \pm 0.03$ & $71.57^{\mathrm{c}} \pm 0.52$ \\
\hline
\end{tabular}




\begin{tabular}{lllllr}
\hline O80C20 & $5.84^{\mathrm{a}} \pm 0.06$ & $12.56^{\mathrm{c}} \pm 0.00$ & $7.18^{\mathrm{a}} \pm 0.12$ & $0.49^{\mathrm{a}} \pm 0.01$ & $1.67^{\mathrm{a}} \pm 0.39$ \\
O80C 20 & $5.84^{\mathrm{a}} \pm 0.06$ & $12.56^{\mathrm{c}} \pm 0.00$ & $7.18^{\mathrm{a}} \pm 0.12$ & $0.49^{\mathrm{a}} \pm 0.01$ & $1.67^{\mathrm{a}} \pm 0.37$ \\
O70C30 & $7.07^{\mathrm{b}} \pm 0.15$ & $14.54^{\mathrm{d}} \pm 0.22$ & $7.82^{\mathrm{b}} \pm 0.09$ & $0.48^{\mathrm{a}} \pm 0.00$ & $2.48^{\mathrm{b}} \pm 0.22$ \\
\hline
\end{tabular}

Values are means of duplicates \pm standard deviation. Different alphabets within a column are significantly different ( $\mathrm{p} \leq 0.05$ ).

$\mathrm{O}=$ oat flour, $\mathrm{C}=$ Defatted cashew nut flour

\section{B. Functional Properties of the flour and Extrudates}

Presented in Table IV are the results of functional analysis of the flour blend samples. Significant $(p<0.05)$ differences were observed in the swelling power and water absorption capacity of the flour samples while there were no significant differences $(p>0.05)$ in the solubility index and the oil absorption capacity. The values for swelling capacity, solubility index, water and oil absorption capacity of the flours varied between 110.56 and $121.15 \mathrm{~g} / \mathrm{g}, 5.50$ and $11.50 \%, 2.11$ and $2.30 \mathrm{~g} / \mathrm{gml}^{-1}$ and 0.56 and $0.66 \mathrm{~g} / \mathrm{ml}$ respectively. Sample $\mathrm{O}_{70} \mathrm{C}_{30}$ had the least swelling power and sample ${ }_{80} \mathrm{C}_{20}$ the highest swelling power value. Swelling capacity, is the amount of moisture uptake that can cause a swelling in flour, was significantly affected by the decreased defatted cashew nut flour inclusion. Oat flour, due to its high fibre content, tends to give room for more moisture absorption in the flour blends thus affecting its swelling capacity positively [27].

It was observed that defatted cashew nut flour substitution had a significant effect on the decrease of the solubility index of the flour with sample $\mathrm{O}_{60} \mathrm{C}_{40}$ with the least value while sample $\mathrm{O}_{80} \mathrm{C}_{20}$ had the highest solubility index. The solubility index, a measure of how well a food easily dissolves in water was influenced by the flour combinations. The higher values for solubility index is proportional the starch composition of the flour blend as influenced by the oat flour.

Sample $\mathrm{O}_{70} \mathrm{C}_{30}$ had the least water absorption capacity value and sample $\mathrm{O}_{65} \mathrm{C}_{35}$ the highest value. The water absorption capacity of the flour blends, which is the ability of the flour sample to hold water after centrifugation, was observed to be low; as a result of the lipid content of the cashew nut flour, impeding on the water absorption of the flour sample.

As defatted cashew nut flour content increased, the oil absorption capacity decreased. Sample $\mathrm{O}_{70} \mathrm{C}_{30}$ had least value while sample $\mathrm{O}_{80} \mathrm{C}_{2}$ the highest value. [28] reported that oil absorption capacity is essential in food product development as fat improves the taste and flavour of foods. The oil absorption capacity blends could be related to the hydrophobic nature of the cashew nut flour which showed higher binding to lipids. The oil absorption value of the flour blends falls within the range reported by [29] which is between 60.70 and $80.0 \mathrm{~g} / \mathrm{ml}$ and lower than those reported by [30] which is between $1.0 \mathrm{~g} / \mathrm{ml}$ and $2.5 \mathrm{~g} / \mathrm{ml}$.

Presented in Table $\mathrm{V}$ is the result of functional properties of the functional extrudates. The water absorption capacity was significantly different $(\mathrm{p}<0.05)$ across the blends. The values ranged between 1.02 and $1.04 \%$.Sample $\mathrm{O}_{75} \mathrm{C}_{25}$ had least value while sample $\mathrm{O}_{65} \mathrm{C}_{35}$ the highest water absorption capacity. Increase in defatted cashew nut flour in the flour blends led to higher water absorption capacity of the extrudates. WAC is described as the potential of a food material to associate with water under a limited condition [31].High WAC is related to loose structure of the starchy components and WAC suggests the compactness of the molecular structure of the starchy components. Therefore, the flour has good ability to bind to water because of its low water absorption capacity. [32] stated that the potential of food product to absorb moisture is significantly correlated with the starch components of the sample.

The bulk density of the extrudates showed no significant difference $(\mathrm{p}>0.05)$ across the samples. All the samples had similar bulk densities. Bulk density is an index of packaging and compactness of the extrudates. The values obtained from this results $(0.67 \mathrm{~g} / \mathrm{ml})$ are close to the range of values 0.55 to $0.62 \mathrm{~g} / \mathrm{ml}$ reported by [33]. It is affected by the nature of the starch constituents and when this is not compact, could mean a low bulk density. This low bulk density suggests that all the flour samples can find utilization in foods without the suspicion of retro-degradation and also desirable in preparation of food that requires low bulkiness [34].

TABLE IV: FUNCTIONAL PROPERTIES OF OAT AND DEFATTED CASHEW NUT FLOUR BLENDS

\begin{tabular}{|c|c|c|c|c|}
\hline Ratios & $\begin{array}{l}\text { Swelling Power } \\
(\%)\end{array}$ & $\begin{array}{l}\text { Solubility } \\
\text { Index (\%) }\end{array}$ & $\begin{array}{l}\text { Water Absorption } \\
\text { Capacity }\left(\mathrm{g} / \mathrm{g}^{-1}\right)\end{array}$ & $\begin{array}{l}\text { Oil Absorption } \\
\text { Capacity (g/goil) }\end{array}$ \\
\hline $\mathrm{O}_{65} \mathrm{C}_{35}$ & $117.14^{\mathrm{bc}} \pm 3.02$ & $9.00^{\mathrm{c}} \pm 0.00$ & $2.34^{\mathrm{b}} \pm 0.06$ & $0.64^{\mathrm{b}} \pm 0.01$ \\
\hline $\mathrm{O}_{70} \mathrm{C}_{30}$ & $110.56^{\mathrm{a}} \pm 2.57$ & $10.50^{\mathrm{d}} \pm 0.71$ & $2.11^{\mathrm{a}} \pm 0.02$ & $0.56^{\mathrm{a}} \pm 0.00$ \\
\hline $\mathrm{O}_{60} \mathrm{C}_{40}$ & $116.93^{\mathrm{bc}} \pm 2.19$ & $5.50^{\mathrm{a}} \pm 2.12$ & $2.15^{\mathrm{a}} \pm 0.08$ & $0.63^{b} \pm 0.04$ \\
\hline $\mathrm{O}_{75} \mathrm{C}_{25}$ & $121.15^{\mathrm{c}} \pm 1.36$ & $7.50^{\mathrm{b}} \pm 2.12$ & $2.21^{\mathrm{ab}} \pm 0.06$ & $0.63^{\mathrm{b}} \pm 0.02$ \\
\hline $\mathrm{O}_{60} \mathrm{C}_{40}$ & $116.93^{\mathrm{bc}} \pm 2.19$ & $5.50^{\mathrm{a}} \pm 2.12$ & $2.15^{\mathrm{a}} \pm 0.08$ & $0.63^{\mathrm{b}} \pm 0.04$ \\
\hline $\mathrm{O}_{80} \mathrm{C}_{20}$ & $118.22^{\mathrm{bc}} \pm 3.04$ & $11.50^{\mathrm{e}} \pm 6.36$ & $2.30^{\mathrm{b}} \pm 0.00$ & $0.66^{\mathrm{b}} \pm 0.06$ \\
\hline $\mathrm{O}_{80} \mathrm{C}_{20}$ & $118.22^{\mathrm{bc}} \pm 3.04$ & $11.50^{\mathrm{e}} \pm 6.35$ & $2.30^{\mathrm{b}} \pm 0.01$ & $0.66^{\mathrm{b}} \pm 0.05$ \\
\hline $\mathrm{O}_{70} \mathrm{C}_{30}$ & $113.88^{\mathrm{a}} \pm 2.13$ & $7.50^{b} \pm 4.95$ & $2.15^{\mathrm{a}} \pm 0.08$ & $0.61^{b} \pm 0.07$ \\
\hline
\end{tabular}

Values are means duplicates \pm standard deviation. Different alphabets in a column are significantly different $(\mathrm{p} \leq 0.05)$.

$\mathrm{O}=$ oat flour, $\mathrm{C}=$ Defatted cashew nut flour 


\begin{tabular}{lccc}
\hline Sample & $\begin{array}{c}\text { Bulk Density } \\
(\mathbf{g} / \mathbf{m L})\end{array}$ & $\begin{array}{c}\text { Expansion Ratio } \\
(\mathbf{m m})\end{array}$ & $\begin{array}{c}\text { Water Absorption } \\
\text { Capacity } \\
\left(\mathbf{g} / \mathbf{g}^{\mathbf{- 1}}\right)\end{array}$ \\
\hline $\mathrm{O}_{65} \mathrm{C}_{35}$ & $0.67^{\mathrm{a}} \pm 0.01$ & $23.29^{\mathrm{d}} \pm 0.01$ & $1.04^{\mathrm{b}} \pm 0.01$ \\
$\mathrm{O}_{70} \mathrm{C}_{30}$ & $0.70^{\mathrm{a}} \pm 0.02$ & $18.74^{\mathrm{b}} \pm 0.01$ & $1.02^{\mathrm{a}} \pm 0.01$ \\
$\mathrm{O}_{60} \mathrm{C}_{40}$ & $0.65^{\mathrm{a}} \pm 0.02$ & $16.56^{\mathrm{a}} \pm 0.01$ & $1.03^{\mathrm{b}} \pm 0.01$ \\
$\mathrm{O}_{75} \mathrm{C}_{25}$ & $0.73^{\mathrm{a}} \pm 0.01$ & $21.10^{\mathrm{c}} \pm 0.01$ & $1.04^{\mathrm{a}} \pm 0.00$ \\
$\mathrm{O}_{60} \mathrm{C}_{40}$ & $0.65^{\mathrm{a}} \pm 0.02$ & $16.56^{\mathrm{a}} \pm 0.01$ & $1.03^{\mathrm{a}} \pm 0.01$ \\
$\mathrm{O}_{80} \mathrm{C}_{20}$ & $0.79^{\mathrm{a}} \pm 0.01$ & $25.56^{\mathrm{e}} \pm 0.01$ & $1.02^{\mathrm{a}} \pm 0.01$ \\
$\mathrm{O}_{80} \mathrm{C}_{20}$ & $0.79^{\mathrm{a}} \pm 0.01$ & $25.56^{\mathrm{e}} \pm 0.01$ & $1.02^{\mathrm{a}} \pm 0.01$ \\
$\mathrm{O}_{70} \mathrm{C}_{30}$ & $0.70^{\mathrm{a}} \pm 0.02$ & $18.74^{\mathrm{b}} \pm 0.01$ & $1.05^{\mathrm{ab}} 0.01$ \\
\hline
\end{tabular}

Values are means duplicates \pm standard deviation. Different alphabets in the same column are significantly different ( $\mathrm{p} \leq 0.05$ ).

$\mathrm{O}=$ oat flour, $\mathrm{C}=$ Defatted cashew nut flour

\section{Pasting Characteristics of the Oat-Defatted Cashew nut flour}

Table VI show results for pasting characteristics of the composite oat-defatted cashew nut flour. Significant differences $(p \leq 0.05)$ was observed across the parameters except for pasting temperature. The peak, trough, breakdown, final and setback viscosities values ranged from 1323.00 to $2023.50,1247.00$ to $17716.50,76.00$ to $307.00,1990.00$ to 2809.50, 743.00 to $1093.00 \mathrm{RVU}$ respectively, while pasting temperature and peak time ranged between 90.45 and $91.73^{\circ} \mathrm{C}$ and 5.53 and 5.80 mins respectively.

The peak, trough, breakdown, final and setback viscosities decreased as defatted cashew nut flour inclusion increased. Sample $\mathrm{O}_{60} \mathrm{C}_{40}$ had the least values. Samples $\mathrm{O}_{70} \mathrm{C}_{30}$ had the highest viscosities, which increased as the defatted cashew nut flour increased. The peak time also followed similar pattern. Sample $\mathrm{O}_{60} \mathrm{C}_{40}$ had the least viscosities and sample $\mathrm{O}_{70} \mathrm{C}_{30}$ had the highest. The pasting temperature increased as the defatted cashew nut flour inclusion decreased. Sample $\mathrm{O}_{70} \mathrm{C}_{30}$ had the least value while sample $\mathrm{O}_{80} \mathrm{C}_{20}$ had the highest value.

Peak viscosity is the highest attainable viscosity upon heating and the capacity of a starch to bind water [35].
Significant difference $(\mathrm{P}<0.05)$ was observed in the peak viscosity of the flour blends. The peak viscosity of the composite flour was observed to increase as the defatted cashew nut flour inclusion decreased. This may be associated to the starch content of the blends and an indication that the flour samples could find a useful application in the food system that requires stable high viscosities especially during cooling [36]. Increase in the breakdown viscosity of the flour blends may lead to gel stability of the flour blends after gelatinization [37]. Differences in the final viscosity of flour blends may be linked to the kinetic effect of cooling on viscosity and the re-association of starch granules in the flour blends [38].

Set back viscosity is resistance of a starch to retrogradation [39]. Low setback viscosity is associated with greater resistance to retrogradation. Therefore, these flours will exhibit higher resistance to retrogradation, and will be useful in other culinary purposes. The peak time is the lowest time required for the flour blends to gelatinize. The results from this study shows a low peak time, which implies a low energy consumption to gelatinize. The pasting temperature shows no significant difference $(p \leq 0.05)$ across the flour blends, which is an indication that the energy requirement for the cooking of the flour will be high.

TABLE VI: PASTING CHARACTERISTICS OF OAT-DEFATTED CASHEW NUT FLOUR BLENDS

\begin{tabular}{llllllll}
\hline Ratios & $\begin{array}{l}\text { Peak } \\
\text { Viscosity } \\
(\mathbf{R V U})\end{array}$ & $\begin{array}{l}\text { Trough } \\
\text { Viscosity } \\
(\mathbf{R V U})\end{array}$ & $\begin{array}{l}\text { Breakdown Viscosity } \\
(\mathbf{R V U})\end{array}$ & $\begin{array}{l}\text { Final } \\
\text { Viscosity } \\
(\mathbf{R V U})\end{array}$ & $\begin{array}{c}\text { Setback } \\
\text { Viscosity } \\
(\mathbf{R V U})\end{array}$ & $\begin{array}{l}\text { Peak } \\
\text { Time } \\
(\text { Mins) }\end{array}$ & $\begin{array}{l}\text { Pasting } \\
\text { Temperature } \\
\left({ }^{\circ} \mathbf{C}\right)\end{array}$ \\
\hline $\mathrm{O} 65 \mathrm{C} 35$ & $1400.00^{\mathrm{b}} \pm 12.73$ & $1266.00^{\mathrm{b}} \pm 12.73$ & $134.00^{\mathrm{c}} \pm 0.00$ & $2078.00^{\mathrm{b}} \pm 142.32$ & $812.00^{\mathrm{b}} \pm 12.73$ & $5.70^{\mathrm{b}} \pm 0.04$ & $91.20^{\mathrm{b}} \pm 1.13$ \\
$\mathrm{O} 70 \mathrm{C} 30$ & $2023.50^{\mathrm{d}} \pm 135.06$ & $1716.50^{\mathrm{c}} \pm 43.13$ & $307.00^{\mathrm{d}} \pm 91.92$ & $2809.50^{\mathrm{d}} \pm 119.50$ & $1093.00^{\mathrm{d}} \pm 76.37$ & $5.80^{\mathrm{c}} \pm 0.00$ & $90.45^{\mathrm{a}} \pm 0.07$ \\
$\mathrm{O} 60 \mathrm{C} 40$ & $1323.00^{\mathrm{a}} \pm 260.22$ & $1247.00^{\mathrm{a}} \pm 197.99$ & $76.00^{\mathrm{a}} \pm 62.23$ & $1990.00^{\mathrm{a}} \pm 343.65$ & $743.00^{\mathrm{a}} \pm 145.66$ & $5.53^{\mathrm{a}} \pm 0.00$ & $91.28^{\mathrm{b}} \pm 1.17$ \\
$\mathrm{O} 75 \mathrm{C} 25$ & $1678.50^{\mathrm{c}} \pm 115.26$ & $1503.50^{\mathrm{c}} \pm 81.32$ & $175.00^{\mathrm{c}} \pm 33.94$ & $2445.00^{\mathrm{c}} \pm 132.94$ & $941.50^{\mathrm{c}} 51.62$ & $5.74^{\mathrm{b}} \pm 0.09$ & $90.88^{\mathrm{a}} \pm 0.46$ \\
$\mathrm{O} 60 \mathrm{C} 40$ & $1323.00^{\mathrm{a}} \pm 260.22$ & $1247.00^{\mathrm{a}} \pm 197.99$ & $76.00^{\mathrm{a}} \pm 62.23$ & $1990.00^{\mathrm{a}} \pm 343.65$ & $743.00^{\mathrm{a}} \pm 145.66$ & $5.53^{\mathrm{a}} \pm 0.00$ & $91.2 \mathrm{~b}^{\mathrm{b}} \pm 1.17$ \\
$\mathrm{O} 80 \mathrm{C} 20$ & $1421.50^{\mathrm{b}} \pm 40.31$ & $1313.00^{\mathrm{b}} \pm 43.84$ & $108.50^{\mathrm{b}} \pm 3.54$ & $2115.50^{\mathrm{b}} \pm 40.31$ & $802.50^{\mathrm{b}} \pm 3.54$ & $5.60^{\mathrm{a}} \pm 0.00$ & $91.73^{\mathrm{c}} \pm 0.60$ \\
$\mathrm{O} 80 \mathrm{C} 20$ & $1421.50^{\mathrm{b}} \pm 40.31$ & $1313.00^{\mathrm{b}} \pm 43.85$ & $108.50^{\mathrm{b}} \pm 3.50$ & $2115.50^{\mathrm{b}} \pm 40.30$ & $802.50^{\mathrm{b}} \pm 3.50$ & $5.60^{\mathrm{a}} \pm 0.01$ & $91.73^{\mathrm{c}} \pm 0.61$ \\
$\mathrm{O} 70 \mathrm{C} 30$ & $2023.50^{\mathrm{d}} \pm 135.06$ & $1716.50^{\mathrm{c}} \pm 43.13$ & $307.00^{\mathrm{d}} \pm 91.92$ & $2809.50^{\mathrm{d}} \pm 119.50$ & $1093.00^{\mathrm{d}} \pm 76.37$ & $5.80^{\mathrm{c}} \pm 0.00$ & $90.45^{\mathrm{a}} \pm 0.07$ \\
\hline
\end{tabular}

Values are means duplicates \pm standard deviation. Different alphabets in a column are significantly different $(\mathrm{p} \leq 0.05)$.

$\mathrm{O}=$ oat flour, $\mathrm{C}=$ Defatted cashew nut flour 


\section{Textural Properties of the Extrudates}

The results of the textural analysis (peak force, chewiness, gumminess, stringiness, adhesiveness, resilience, stickiness, springiness and cohesiveness) of the extrudates are shown in Table VII. Significant differences $(\mathrm{p} \leq 0.05)$ exists across the extrudates. Sample $\mathrm{O}_{70} \mathrm{C}_{30}$ had the least peak force value and sample $\mathrm{O}_{80} \mathrm{C}_{20}$ had the highest value. The peak force increased as the defatted cashew nut flour decreased and this increase may be attributed to the starch content of the oat flour. Chewiness, related to the elasticity of a food sample, ranged between 160 and $828 \mathrm{~g}$. Chewiness tended to increase as the defatted cashew nut flour decreased and this may due to the high fibre content of the oat flour which absorbs water and gelatinize during cooking, thus making it more elastic and chewy [40].Adhesiveness is the force of attraction between the food component and its external environment, ranged between 0.01 and $1.52 \mathrm{~g}$. The results obtained showed that as the defatted cashew nut flour increased, the adhesiveness also increased. This may be due to the lipid content of the cashew nut flour. Cashew nut is reported to be a rich source of lipids [41]. Resilience which is a measure of toughness of the extrudates increased with increased level of oat flour inclusion. Increase in resilience may be associated with the fibre content of the oat flour which has been attributed to have a positive effect on the resilience of the extrudates [42].

TABLE VII: MEAN VALUES OF TEXTURE PROFILE ANALYSIS OF THE FUNCTIONAL EXTRUDATES

\begin{tabular}{|c|c|c|c|c|c|c|c|c|c|}
\hline Sample & $\begin{array}{l}\text { Peak Force } \\
\text { (N) }\end{array}$ & Chewiness & Gumminess & Stringiness & Adhesiveness & Resilience & Stickiness (g) & $\begin{array}{l}\text { Springiness } \\
\text { (g) }\end{array}$ & $\begin{array}{l}\text { Cohesiveness } \\
\text { (g) }\end{array}$ \\
\hline $\mathrm{O}_{65} \mathrm{C}_{35}$ & $10408.00 \pm .22$ & $160.00 \pm .22$ & $2730.00 \pm .22$ & $3.55 \pm .22$ & $0.90 \pm .22$ & $0.25 \pm .22$ & $2.00 \pm .22$ & 0.06 & 0.26 \\
\hline $\mathbf{O}_{70} \mathrm{C}_{30}$ & $6396.00 \pm .22$ & $226.00 \pm .22$ & $2889.00 \pm .22$ & $2.61 \pm .22$ & $1.52 \pm .22$ & $0.14 \pm .22$ & $3.00 \pm .22$ & 0.08 & 0.45 \\
\hline $\mathrm{O}_{60} \mathrm{C}_{40}$ & $10900.00 \pm .22$ & $828.00 \pm .22$ & $6804.00 \pm .22$ & $0.24 \pm .22$ & $0.76 \pm .22$ & $0.24 \pm .22$ & $2.00 \pm .22$ & 0.12 & 0.62 \\
\hline $\mathrm{O}_{75} \mathrm{C}_{25}$ & $9426.00 \pm .22$ & $825.00 \pm .22$ & $6698.00 \pm .22$ & $0.05 \pm .22$ & $0.01 \pm .22$ & $0.25 \pm .22$ & $1.00 \pm .22$ & 0.12 & 0.71 \\
\hline $\mathrm{O}_{60} \mathrm{C}_{40}$ & $10900.00 \pm .22$ & $828.00 \pm .22$ & $6804.00 \pm .22$ & $0.24 \pm .22$ & $0.76 \pm .22$ & $0.24 \pm .22$ & $2.00 \pm .22$ & 0.12 & 0.62 \\
\hline $\mathrm{O}_{80} \mathrm{C}_{20}$ & $26784.00 \pm .22$ & $749.00 \pm .22$ & $8884.00 \pm .22$ & $0.35 \pm .22$ & $0.29 \pm .22$ & $0.52 \pm .22$ & $2.00 \pm .22$ & 0.28 & 0.71 \\
\hline $\mathrm{O}_{80} \mathrm{C}_{20}$ & $26784.00 \pm .22$ & $749.00 \pm .22$ & $8884.00 \pm .22$ & $0.35 \pm .22$ & $0.29 \pm .22$ & $0.52 \pm .22$ & $2.00 \pm .22$ & 0.28 & 0.71 \\
\hline $\mathbf{O}_{70} \mathbf{C}_{30}$ & $6396.00 \pm .22$ & $226.00 \pm .22$ & $2889.00 \pm .22$ & $2.61 \pm .22$ & $1.52 \pm .22$ & $0.14 \pm .22$ & $3.00 \pm .22$ & 0.08 & 0.45 \\
\hline
\end{tabular}

Values are means duplicates \pm standard deviation. Different alphabets in a same column are significantly different ( $\mathrm{p} \leq 0.05)$.

$\mathrm{O}=$ oat flour, $\mathrm{C}=$ Defatted cashew nut flour

\section{E. Sensory Evaluation of the Extrudates}

Table VIII shows the results for the sensory evaluation of the extrudates. The mean scores of the sensory analysis of the extrudates showed that the samples are well accepted.
Significant differences does not exist $(\mathrm{p} \leq 0.05)$ in the sensory attribute of the extrudates. This could be attributed to the homogenization and extrusion effect on the extrudates. Extrusion has been reported to significantly influence the sensory qualities of food.

TABLE VIII: SENSORY PROPERTIES OF THE FUNCTIONAL EXTRUDATES

\begin{tabular}{|c|c|c|c|c|c|}
\hline Samples & Colour & Aroma & Texture & Taste & Overall Acceptability \\
\hline O65C35 & $8.75^{\mathrm{b}} \pm 1.62$ & $7.90^{\mathrm{a}} \pm 1.52$ & $8.20^{\mathrm{a}} \pm 1.74$ & $8.45^{\mathrm{b}} \pm 1.76$ & $8.55^{\mathrm{c}} \pm 1.88$ \\
\hline O70C30 & $8.35^{\mathrm{a}} \pm 1.53$ & $8.40^{\mathrm{a}} \pm 1.31$ & $8.35^{\mathrm{a}} \pm 1.42$ & $7.90^{\mathrm{a}} \pm 1.71$ & $8.30^{\mathrm{b}} \pm 1.95$ \\
\hline O60C40 & $8.40^{\mathrm{b}} \pm 1.88$ & $8.55^{\mathrm{a}} \pm 1.00$ & $8.25^{\mathrm{a}} \pm 1.59$ & $8.15^{\mathrm{a}} \pm 1.81$ & $8.25^{\mathrm{b}} \pm 1.25$ \\
\hline O75C25 & $8.4 b^{\mathrm{a}} \pm 1.70$ & $8.25^{\mathrm{b}} \pm 1.41$ & $8.20^{\mathrm{a}} \pm 1.51$ & $8.35^{\mathrm{b}} \pm 1.73$ & $8.65^{\mathrm{c}} \pm 1.84$ \\
\hline O60C40 & $8.40^{\mathrm{a}} \pm 1.88$ & $8.55^{\mathrm{b}} \pm 1.00$ & $8.25^{\mathrm{a}} \pm 1.59$ & $8.15^{\mathrm{a}} \pm 1.81$ & $8.25^{\mathrm{b}} \pm 1.25$ \\
\hline O80C20 & $8.25^{\mathrm{a}} \pm 1.12$ & $8.00^{\mathrm{b}} \pm 1.08$ & $8.90^{\mathrm{b}} \pm 1.48$ & $7.90^{\mathrm{a}} \pm 1.83$ & $7.95^{\mathrm{a}} \pm 1.43$ \\
\hline $080 C 20$ & $8.25^{\mathrm{a}} \pm 1.12$ & $8.00^{\mathrm{b}} \pm 1.08$ & $8.90^{\mathrm{b}} \pm 1.48$ & $7.90^{\mathrm{a}} \pm 1.83$ & $7.95^{\mathrm{a}} \pm 1.43$ \\
\hline O70C30 & $8.35^{\mathrm{a}} \pm 1.53$ & $8.40^{\mathrm{b}} \pm 1.31$ & $8.35^{\mathrm{a}} \pm 1.42$ & $7.90^{\mathrm{a}} \pm 1.71$ & $8.30^{\mathrm{b}} \pm 1.95$ \\
\hline
\end{tabular}

Values are means duplicates \pm standard deviation. Different alphabets in a column are significantly different $(\mathrm{p} \leq 0.05)$.

$\mathrm{O}=$ oat flour, $\mathrm{C}=$ cashew nut flour

\section{CONCLUSION}

It is concluded that functional extrudates can be produced from whole Oat and defatted Cashew nut flour. The study established that substitution of Oat flour with Cashew nut flour increased the protein and crude fibre of the extrudates with low bulkiness but chewy extrudates. The Samples were generally acceptable, being highly rated in terms of all parameters with a moderate likeness. Sample $\mathrm{O}_{75} \mathrm{C}_{25}$ was rated most acceptable (8.65) with regards to overall acceptability. The study confirms that extrusion cooking can be used to a produce a functional extrudates that can increase utilization of nutritious cashew nut which use is limited to confectionery in Nigeria.

\section{Acknowledgments}

Authors acknowledge the support of staff of the Food Processing and Chemistry Laboratories of the Department of 
Food Technology, Yaba College of Technology, Yaba, Lagos, Nigeria.

\section{Conflicts of Interest}

No conflict of interest.

\section{REFERENCES}

[1] Arai, S. (1996). Studies on functional foods in Japan state of the art Bioscience. Biotechnology. Biochemistry. 60: 9-15.

[2] Heuzé V. Tran G. Nozière P. Renaudeau D. Lessire M. Lebas F. (2016). Oats. Feedipedia, a programme by INRA, CIRAD, AFZ and FAO.

[3] Ogunwolu, S.O., Henshaw F.O., Mock, H.P. and Matros A. (2010). Production protein concentrate and isolate from cashew (Anacardiumoccidentale) Nut. African journal of food agriculture, Nutrition and development. Volume 10 No 5 p: 2501-2513.

[4] Kim J. H, Tanhehco E.J. (2006). Effects of extrusion conditions on resistant starch formation from pastry wheat flour. Food Chem. 99:718-723.Doi.org/10.1016/j.foodchem.2005.08.054.

Doi.org/10.1016/j.foodchem.2005.08.054

[5] Ogunwolu S.O, Ogunjobi, M.A.K (2010). Physiochemical and sensory properties of cassava flour biscuits supplemented with cashew apple powder. Journal of Food Technology, 8(1), 24-29.

[6] Lobato, L.P., Anibal, D., Lazaretti, M M., and Grossmann, M.V. E. (2011). Extruded puffed functional ingredient with oat bran and soy flour. LWR-Food Science and Technology 44:933-939.DOI: 10.1016/j.lwt.2010.11.013

[7] AOAC (2005). Official methods of analysis ofAOAC international. Method 985.29 (17th ed.). Washington, DC: The Association.

[8] Robertson G.L., Monredon F.D., Dysseler P., Guillon F., Amado R., Thibault J. F, (2000). Lebensm. Wiss - Technology, 33 72-79.

[9] Ade-Omowaye B. I. O,Akinwande B.A., Bolarinwa I.F. and Adebiyi A.O. (2008). Evaluation of tigernut (Cyperusesculentus) wheat composite flour and bread. Afr. J.Food Sci., 2: 87-91

[10] Ade-Omowaye B. I. O., Akinwande B.A, ,Bolarinwa I.F. and Adebiyi A.O.,(2008). Evaluation of tigernut (Cyperusesculentus) wheat composite flour and bread. Afr. J.Food Sci., 2: 87-91. DOI: 10.12691/jfnr-3-7-1.

[11] Newport Scientific, (1998). Applications Manual for the Rapid ViscoAnalyser. Newport Scientific Pty. Ltd. Australia, pp: 36-58.

[12] Fan, J., Mitchel J.R., and Blanchard, J.M.V (1996). The effect of sugars on the extrusion of maize grits: InI, Starch conversion. Int J of Food Sci 31:67-76.DOI: org/10.1111/j.1365-2621.1996.22-317.x

[13] Bourne, M.C. (1978). Texture profile analysis, Food Technology, 32(7). 62-72

[14] Iwe, M.O. (2003). Handbook of sensory method and analysis. Publ. Rejoint communication services ltd. Uwani Enugu, Nigeria.

[15] Akanbi T.O., Nazamid, S. and Adebowale, A.A. (2009). Functional and pasting properties of a tropical breadfruit (Artocarpusaltilis) starch from Ile-Ife, Osun State, Nigeria. International Food Research Journal 16: 151-157.

[16] FAO, (1992). Food and Nutrition paper: Manual of food quality control. Rome, Italy. Frying. Lebensmittel-Wissenschaft-undTechnologie, 36, 43-48.

[17] Omosuli S.V, Ibrahim T.A and Oloye D. (2009). Proximate and mineral composition of roasted and defatted cashew nut flour. Patistan Journal of Nutrition, 8(10), 1649 -1651. DOI: 10.3923/pjn.2009.1649.1651

[18] Lobato, L.P., Anibal, D., Lazaretti, M M., and Grossmann, M.V. E. (2011). Extruded puffed functional ingredient with oat bran and soy flour. LWR-Food Science and Technology 44:933-939.DOI: 10.1016/j.lwt.2010.11.013

[19] Peterson, D.M., (2002), Oat lipids composition, Separation and applications. Lipids Technology, 14, 56-59.

[20] Emelike N.J.T and Ebere C.O (2015). Effect of packaging materials, storage time and temperature on the colour and sensory characteristics of cashew (Anacardiumoccidentale L.) apple juice. Journal of Food and Nutrition Research, 3(7), 410 - 414.DOI: 10.12691/jfnr-3-7-1.

[21] Lobato, L.P., Anibal, D., Lazaretti, M M., and Grossmann, M.V. E. (2011). Extruded puffed functional ingredient with oat bran and soy flour. LWR-Food Science and Technology 44:933-939.DOI: 10.1016/j.lwt.2010.11.013
[22] Omosuli S.V, Ibrahim T.A and Oloye D. (2009). Proximate and mineral composition of roasted and defatted cashew nut flour. Patistan Journal of Nutrition, 8(10), 1649 -1651.DOI: 10.3923/pjn.2009.1649.1651

[23] Moraru, C.I and Kokini, J.L (2003). Nucleation and expansion during extrusion and microwave heating of cereal foods. Comprehension reviews in food science and food safety, 2, 147165.Doi.org/10.1111/j.1541-4337.2003.tb00020

[24] Brennan,M.A.;Derbyshire,E.;Tiwari,B.K.;Brennan,C.S.Ready-toeatsnackproducts: Theroleofextrusion technology in developing consumer acceptable and nutritious snacks. Int. J. Food Sci. Technol. 2013, 48, 893-902.

[25] Pastor-

Cavada,E.;Drago,S.R.;Gonzalez,R.J.;Juan,R.;Pastor,J.E.;Alaiz,M.;V ioque,J.Effectsoftheaddition of wild legumes (Lathyrus annuus and Lathyrus clymenum) on the physical and nutritional properties of extruded products based on whole corn and brown rice. Food Chem. 2011, 128, 961-967.

[26] Kinsella J.E. (1976). Functional properties of proteins in foods. Critical Reviews in Food Science and Nutrition 1(3): 219280.Doi.org/10.1080/10408397609527208

[27] Ikegwu, O.J, Nwobasi V.N, Odoh, M.O and Oledinma, N.U. (2009). Evaluation of the pasting and some functional properties of starch isolated from some improved cassava varieties in Nigeria. African J. of Biotech 8(10): 2310-2315.

[28] Omodamiro, R.M., Iwe, M.O. and Ukpabi, U.J. (2007). Pasting and Functional properties of lafunand starch processed from some improved cassava genotypes in Nigeria. Niger. Food J. 25(2): 122126. DOI: $10.4314 /$ nifoj.v25i2.50849

[29] Oladele, A. K. and Aina, J. O. (2007). Chemical composition and functional properties of flour from two varieties of tigernut (Cyperusesculentus). African Journal of Biotechnology. 6(21): 24732476

[30] Plaami, S. P. (1997). Content of dietary fibre in foods and its physiological effects, Food Rev. International. 13:2776.DOI.org/10.1080/87559129709541097.

[31] Omueti, O., Otegbayo, B., Jaiyeola, O., andAfolabi, O. (2009). Functional properties of complementary dietsdeveloped from soybean (Glycine max), groundnut (Arachis hypogeal) and crayfish (macrobrachiumspp).J. Environ. Agricultural and Food Chem. 8 (8): 563-573.

[32] Mbofung, C. M. F., Abubakar, Y.N., Nyintang, A., Abduo, B., and Balaam, F. (2006). Physicochemical andfunctional properties of six varieties of taro (Calocasciaesculenta L. Schott) flour. J. Food Technol. 4 (2): 135-14.

[33] Akoja, S.S., and Coker, O.J. (2018) Physicochemical, functional, pasting and sensory properteies of wheat flour biscuit incorporated with okra powder. International Journal of Food Science and Nutrition. Vol. 3 Issue 5, 64-70

[34] Akoja SS, Adebowale OJ, Makanjuola OM, Salaam H (2016). Functional Properties, Nutritional and Sensory Qualities of MaizeBased Snack (Kokoro) Supplemented with Protein Hydrolysate prepared from Pigeon Pea (CajanusCajan) Seed. Journal of Culinary Science and Technology, DOI: 10.1080/15428052. 1259134

[35] Offia-Olua B.I. (2014). Chemical, functional and pasting properties of wheat (Triticumspp)- Walnut (Juglansregia) flour. Food and Nutrition Sciences; 5:1591-1604. Dx.doi.org/10.4236/fns.2014.516172

[36] Offia-Olua B.I. (2014). Chemical, functional and pasting properties of wheat (Triticumspp)- Walnut (Juglansregia) flour. Food and Nutrition Sciences; 5:1591-1604.

[37] Shimelis, A.E., Meaza, M. and Rakshit, S. (2006). Physico-chemical Properties, Pasting Behaviour and Functional Characteristics of Flours and Starches from Improved Bean (Phaseolus Vulgaris L.) varieties Grown in East Africa. CIGR E journal 8: 1-18.

[38] Ikegwu, O.J, Nwobasi V.N, Odoh, M.O and Oledinma, N.U. (2009). Evaluation of the pasting and some functional properties of starch isolated from some improved cassava varieties in Nigeria. African J. of Biotech 8(10): 2310-2315.

[39] Sanni, L. O., Ikuomola, D. P., and Sanni, S. A. (2001). Effect of length of fermentation and varieties on the qualities of sweet potato gari. Proc. 8th triennial Symposium of the International Society for Tropical Root. Crops. Africa Branch (ISTRC-AB), Ed. M.O.

[40] Sibakov, J., Myllymäki, O., Holopainen, U., Kaukovirta-Norja, A.,Hietaniemi, V., Pihlava, J. M., Lehtinen, P. (2011). Lipid removalenhances separation of oat grain cell wall material from 
starch andprotein. Journal of Cereal Science,54(1), 104-109. doi:10.1016/j.jcs.2011.04.003

[41] Emelike N.J.T and Ebere C.O (2015). Effect of packaging materials, storage time and temperature on the colour and sensory characteristics of cashew (Anacardiumoccidentale L.) apple juice. Journal of Food and Nutrition Research, 3(7), 410 - 414.DOI: 10.12691/jfnr-3-7-1.

[42] Lobato, L.P., Anibal, D., Lazaretti, M M., and Grossmann, M.V. E. (2011). Extruded puffed functional ingredient with oat bran and soy flour. LWR-Food Science and Technology 44 :933-939. DOI: 10.1016/j.lwt.2010.11.013

[43] Rhee KS, Cho SH, Pradahn AM. Composition, storage stability and sensory properties of expanded extrudates from blends of corn starch and goat meat, lamb, mutton, spent fowl meat, or beef. Meat Sci. 52:135-141. DOI: 10.1016/S0309-1740(98)00157-0

\section{ABOUT THE AUTHORS}

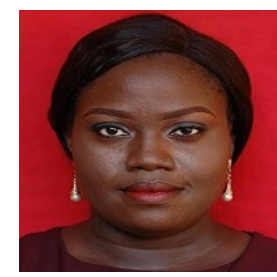

H.T. Olaleye holds a M.Sc. and Ph.D. in Food Processing and Storage Technology. Her research interests are in the areas of processing and preservation of food to reduce wastage, value addition in the food chain, food safety and nutrition, and food storage. Currently, she is currently a lecturer in Food Technology Department, Yaba College of Technology, Lagos, Nigeria.

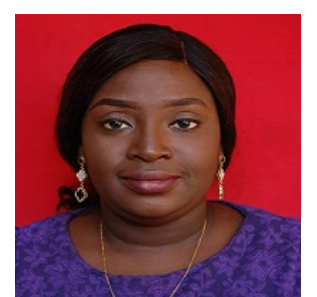

T.O. Oresanya is a Lecturer in the Department of Food Technology, Yaba College of Technology, Yaba, Lagos, Nigeria. She holds a M.Sc. in Food Processing and Storage Technology. Her research interests lie in the areas of Food Chemistry, Food Product Development, Food and Nutrition and Food Processing.

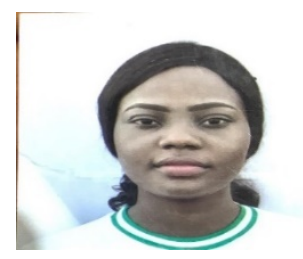

E.M Anderson is a graduate of Food Technology from Yaba College of Technology. Her interest lies in the processing and preservation,easy marketing and distribution

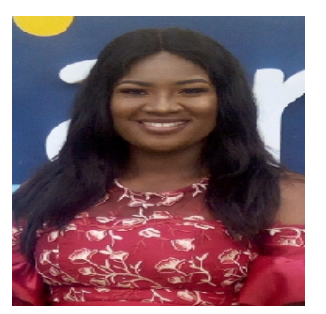

.Z.O Abdullahiholds a Higher National Diploma in Food Technology from Yaba College of Technology. Her research area is in the food processing and nutrition for health. 